\title{
Primary Hepatosplenic Large B-Cell Lymphoma
}

\section{A Rare Aggressive Tumor}

\author{
M.R. Morales-Polanco ${ }^{a} \quad$ R. Drijansky-Morgenstern ${ }^{b}$ \\ E. Murillo-Meza ${ }^{\text {E. Gómez-Morales }}{ }^{\mathrm{a}}$ \\ aHematology and 'bnternal Medicine Department, ABC Medical Center, \\ Mexico City, Mexico
}

\section{Key Words}

Primary extranodal lymphoma $\cdot$ Large B-cell lymphoma $\cdot$ Hepatosplenic

\begin{abstract}
Diffuse large B-cell lymphoma is the most common form of lymphoma. It usually begins in the lymph nodes; up to $40 \%$ may have an extranodal presentation. According to a definition of primary extranodal lymphoma with presentation only in extranodal sites, there are reports of large B-cell lymphomas limited to liver or spleen as separate entities, and to date there have been only three documented cases of primary hepatosplenic presentation. This paper reports a fourth case. Due to a review of the literature and the clinical course of the case reported, we conclude that primary hepatosplenic large B-cell lymphoma has been found predominantly in females older than 60 years. The patients reported had $<2$ months of evolution prior to diagnosis, prominent B symptoms, splenomegaly in three and hepatomegaly in two, none with lymph node involvement. All had thrombocytopenia and abnormal liver function tests; three had anemia and elevated serum lactic dehydrogenase levels, two with hemophagocytosis in bone marrow. Because of the previously mentioned data, it can be stated that primary hepatosplenic lymphoma is an uncommon and aggressive form of disease that requires immediate recognition and treatment.
\end{abstract}

\section{Introduction}

Non-Hodgkin lymphomas (NHL) are a heterogeneous group of lymphoproliferative diseases. Their ontogeny is related with the process of maturation in the lymphoid nodal tissue. Thus, their clinical manifestations generally begin in nodal areas, but in up to $40 \%$ presentation can be primarily extranodal, and clinical behavior may be variable according to the organs and tissues initially involved, sometimes rendering their diagnosis difficult $[1,2]$. 
Primary hepatosplenic presentation has been reported among extranodal forms of NHL; a rare entity, its presence is limited to case reports, the majority of T-cell origin [3]. To date, only three cases of primary hepatosplenic large B-cell lymphoma have been reported, two of these associated with hemophagocytic syndrome (HS) in bone marrow (BM) [4-6].

We report a new patient with primary hepatosplenic diffuse large B-cell lymphoma (DLBCL) as well as HS in BM. Due to the rarity of the condition, its morphologic and phenotypic characteristics, but principally because of the particularly severe clinical manifestations of this case and the patients previously reported, we consider it of interest to review the information regarding all these patients.

\section{Case Report}

A female, 67 years of age, was diagnosed due to anemia in May 2004 with refractory anemia with multilineage dysplasia, and received treatment with folic acid and vitamin B12. In July 2004 the patient complained of night fever up to $104.0^{\circ} \mathrm{F}$, night sweats, and a $13.23 \mathrm{lb}$ weight loss, and received antimicrobial therapy without improvement. In August 2004 she was hospitalized for fever of unknown origin.

At physical examination, she was conscious, cooperative, and with important wasting. Her weight was $116.85 \mathrm{lb}$, height $5.1181 \mathrm{ft}$, blood pressure $105 / 70 \mathrm{~mm} \mathrm{Hg}$, pulse $80 / \mathrm{min}$, respiratory rate $18 / \mathrm{min}$, and temperature $101.3^{\circ} \mathrm{F}$. It is important to mention that the patient presented no adenomegalies, visceromegalies, bone pain, purpura, bleeding, or infectious source.

The laboratory reported the following: hemoglobin $(\mathrm{Hb}) 11.9 \mathrm{~g} / \mathrm{dl}$; hematocrit $(\mathrm{Ht}) 34 \%$; mean corpuscular volume $108 \mathrm{fl}$; mean corpuscular $\mathrm{Hb} 34.5 \mathrm{pg}$; leukocytes $9.2 \times 10^{9} / \mathrm{l}$, with neutrophils $7.0 \times$ $10^{9} / 1$ and lymphocytes $0.6 \times 10^{9} / \mathrm{l}$; platelets $74 \times 10^{9} / \mathrm{l}$; erythrocyte sedimentation rate $52 \mathrm{~mm} / \mathrm{h}$; blood glucose $118 \mathrm{mg} / \mathrm{dl}$; urea nitrogen $18 \mathrm{mg} / \mathrm{dl}$; creatinine $0.9 \mathrm{mg} / \mathrm{dl} ; \mathrm{Na} 129 \mathrm{mEq} / \mathrm{l}, \mathrm{K} 4.0 \mathrm{mEq} / \mathrm{l}$; Cl 100 $\mathrm{mEq} / \mathrm{l}$; total protein $5.2 \mathrm{~g} / \mathrm{l}$, with albumin $2.9 \mathrm{~g} / \mathrm{l}$ and globulin $2.3 \mathrm{~g} / \mathrm{l}$. In addition, ALT was $139 \mathrm{IU} / \mathrm{l}$, AST $91 \mathrm{IU} / 1$, and alkaline phosphatase $304 \mathrm{IU} /$ l, lactic dehydrogenase 1,089 IU/l (normal range 101-208 $\mathrm{IU} / \mathrm{l}$ ), and $\beta-2$ microglobulin 5,825 $\mathrm{ng} / \mathrm{dl}$ (normal range $700-3,400 \mathrm{ng} / \mathrm{dl}$ ).

Computed tomography (CT) of the abdomen and pelvis showed hepatosplenomegaly and thorax was normal, both without evidence of adenopathies. Gallium ${ }^{67}$ scan confirmed visceral enlargement but found no lymph node enlargement or focal uptake in liver, spleen, lymph nodes or other sites. Cultures at different sites were negative, as well as the serological test for hepatitis B and C, cytomegalovirus, human immunodeficiency, and Epstein-Barr virus. Febrile reactions and VDRL tests were negative. BM aspiration and biopsy showed hemophagocytosis of erythrocytes and platelets (fig. 1) and myelodysplastic syndrome abnormalities.

The patient deteriorated rapidly, and within a few days experienced severe falls in $\mathrm{Hb}$ to $8.4 \mathrm{~g} / \mathrm{dl}, \mathrm{Ht}$ to $27 \%$, and platelets to $29 \times 10^{9} /$ l. Therefore, an exploratory laparotomy was performed on September 3,2004 , finding hepatosplenomegaly but no evidence of adenomegalies; splenectomy and wedge liver biopsies were conducted. The spleen weighed $1.82 \mathrm{lb}$, and like the liver biopsy was infiltrated by large lymphoma cells, CD20 positive, with focal positivity for BCL-2 and Ki-67 in $60 \%$ of cells.

Postoperatively, the patient developed Escherichia coli-associated gastroenteritis and at the same time basal pneumonia in left lung with blood cultures positive for coagulase-negative staphylococci. She received antimicrobial therapy with rapid improvement of her clinical condition, allowing us to begin chemotherapy with cyclophosphamide-mitoxantrone-vincristine-prednisone plus rituximab (CNOP-R) for a total of eight cycles. The patient showed remarkable improvement, and from the third cycle on, we observed a steady rise in $\mathrm{Hb}$ and $\mathrm{Ht}$; leukocytes and platelets increased to normal levels, and lactic dehydrogenase and $\beta-2$ microglobulin decreased to normal values. Complete response was achieved and has been sustained until the date of this report. Positron emission tomography-CT scan carried out in July 2007 showed no evidence of disease. 


\section{Discussion}

With regard to this review, one controversial issue comprises the definition of 'extranodal lymphoma'. While some authors consider this diagnosis only when a complete set of studies demonstrates lymphoma activity in a single extranodal site, others describe that an 'extranodal lymphoma' can be considered when the main signs-andsymptoms-related component of the disease is localized in extranodal territory, although minimal nodal compromise coexists. Certain authors have also proposed that extranodal lymphoma can be considered when at least $75 \%$ of the disease is localized in an extranodal area. In this paper, we preferred the first concept [1].

Thus, according to the definition we chose, we found four cases of primary hepatosplenic DLBCL on reviewing the literature [8-10]; however, we rejected the case reported by Gil et al. because in addition to hepatosplenic infiltration, the patient had lymphoma in BM and bones [7]. The remanining three cases reviewed [4-6] only presented hepatosplenic infiltration (table 1).

As we previously mentioned, NHL primarily affect lymphoid node tissue; nonetheless, between 24 and $37 \%$ can have primary extranodal manifestations. The most frequently affected extranodal sites include the following: gastrointestinal tract (mainly stomach), 24\%; Waldeyer's ring, $19 \%$; soft tissues, $19 \%$; testis, $4 \%$; skin, $3.8 \%$; bone, $3.7 \%[1,2]$.

Although there are several reports of cases of hepatic or splenic primary lymphomas as separate entities, primary hepatosplenic lymphomas represent a rare entity, and the majority of cases reported have been of T-cell origin, especially the $\gamma / \delta$ subtype [3], although the presentation of primary hepatosplenic DLBCL is limited to the four cases analyzed in this paper (tables 1 and 2) [4-6], including our own case. Considering the small number of patients, it is not possible to establish definitive conclusions.

Nevertheless, this review allows us to underscore their principal characteristics, such as limited disease localization and the severe clinical manifestations of this rare hepatosplenic tumor. These manifestations included that three of the four patients were $>60$ years of age and three were females. All cases had B symptoms and none had lymph node or other sites of involvement. Three patients had splenomegaly and only two liver enlargement, although all cases had liver function tests abnormalities. The CT and gallium scans showed hepatosplenomegaly in two and isolated splenomegaly in one patient, with focal lesions in patient 1 (table 2). All patients had thrombocytopenia, and three had anemia, these cytopenias being related with lymphoma, splenomegaly, and in two cases with HS.

The disease's clinical course was rapid and aggressive; in two cases, it was fatal in a short period of time. It is noteworthy that our patient had a rapid clinical deterioration with fever, visceromegalies, and a dramatic fall in the pre-existing cytopenias within a few days (table 1) as evidence of disease severity.

The association of NHL with HS has been reported in those of T-cell origin; in relation with B-cell lymphomas, this association has been occasionally found in the subtypes $\mathrm{T}$ cell-rich LBCL and angiotrophic lymphoma [8,9]. Its pathogenesis has been attributed in some cases to the use of granulocyte macrophage colony stimulating factor, and in some others the release of some endogenous factor released by T-cells that stimulate macrophage proliferation and function has also been implicated [10-12]. In certain patients HS appears in relation to viral infections, but neither of the two patients with HS in this report (table 1) had evidence of such an infection type. 
It is considered that increased frequency of lymphomas in general and hepatic or splenic LBCL is related to hepatitis C infection $[8,9]$. Gil et al. reported a young patient with hepatitis $\mathrm{C}$ viral infection who developed an aggressive lymphoma with hepatic, splenic, nodal, bone, and BM infiltration with a fatal outcome within a few days [7]. Two of the cases analyzed (cases 1 and 3) (table 2) had a similar course and both had positive serology for hepatitis $\mathrm{C}$ virus. The exact mechanism responsible for the association between hepatitis $C$ virus and such an aggressive lymphoma is partially unknown $[6,7]$.

Finally, only the two patients who received complete schemes of chemotherapy were able to survive (patients 2 and 4 ) to the acute phase of the lymphoma, with prolonged survival (table 2).

In conclusion, we report the fourth clearly documented case of primary hepatosplenic DLBCL associated with HS. According to the findings of the present review, it is evident that this rare entity tends to appear in females and in individuals of advanced age. It is characterized by severe signs and symptoms, rapid evolution of cytopenias (thrombocytopenia and anemia), abnormalities of liver function tests, and follows a rapid and aggressive, even fatal, clinical evolution.

Consequently, adequate treatment of this disease requires early histologic and immunophenotypic diagnosis. Thus, it is necessary to have this rare variety of lymphoma in mind in patients presenting the characteristics described herein. 
Table 1. Clinical and laboratory findings in four patients with primary hepatosplenic large B-cell lymphoma

\begin{tabular}{|c|c|c|c|c|}
\hline Clinical case & 1 & 2 & 3 & Present case \\
\hline Gender & $\mathrm{F}$ & $\mathrm{F}$ & M & $\mathrm{F}$ \\
\hline Age, years & 74 & 41 & 75 & 67 \\
\hline Evolution, months & 2 & 1 & 2 & 2 \\
\hline B symptoms & + & + & + & + \\
\hline Splenomegaly & + & + & - & + \\
\hline Hepatomegaly & + & - & - & + \\
\hline Adenomegalies & - & - & - & - \\
\hline \multicolumn{5}{|l|}{ Blood cell cytology } \\
\hline Hemoglobin, g/dl & 9.8 & 7.1 & 14.1 & 8.4 \\
\hline Leukocytes, $\times 10^{9} / 1$ & 4.5 & 6.1 & 8.7 & 4.9 \\
\hline Platelets, $\times 10^{9} / 1$ & 70 & 4 & 81 & 29 \\
\hline \multicolumn{5}{|l|}{ Liver function test } \\
\hline AST, IU/dl & 80 & 163 & 134 & 91 \\
\hline ALT, IU/dl & 115 & 42 & 64 & 139 \\
\hline AP, IU/dl & 324 & 575 & 2,502 & 304 \\
\hline GGT, IU/dl & 420 & NA & 482 & 400 \\
\hline LDH, IU/l & NA & 1,948 & 1,805 & 1,089 \\
\hline$\beta-2$ microglobulin, $\mathrm{ng} / \mathrm{ml}$ & NA & 3.5 & NA & 5,825 \\
\hline \multicolumn{5}{|l|}{ Viral serology } \\
\hline $\mathrm{HCV}$ & + & - & + & - \\
\hline $\mathrm{HBV}$ & - & - & - & - \\
\hline CMV & - & - & - & - \\
\hline HIV & - & - & - & - \\
\hline EBV & - & - & - & - \\
\hline Febrile reactions & NA & NA & NA & - \\
\hline
\end{tabular}

$\mathrm{F}=$ Female; $\mathrm{M}=$ male; + = present - = absent $\mathrm{NA}=$ not available; $\mathrm{LDH}=$ lactic dehydrogenase; $\mathrm{HCV}$ = hepatitis $\mathrm{C}$ virus; $\mathrm{HBV}$ = hepatitis $\mathrm{B}$ virus; $\mathrm{CMV}=$ cytomegalovirus; $\mathrm{HIV}=$ human immunodeficiency virus; $\mathrm{EBV}=$ Epstein-Barr virus.

Table 2. Imaging and histopathologic studies and treatment

\begin{tabular}{lllll}
\hline Case & 1 & 2 & 3 & Present case \\
\hline Computed tomography & $\begin{array}{l}\text { liver: } 4 \text { nodes } \\
\text { spleen: } 1 \text { node } \\
\text { ascitis }\end{array}$ & $\begin{array}{l}\text { splenomegaly/ } \\
\text { infarction }\end{array}$ & $\begin{array}{l}\text { hepatomegaly } \\
\text { splenomegaly }\end{array}$ & $\begin{array}{l}\text { hepatomegaly } \\
\text { splenomegaly }\end{array}$ \\
\hline Gallium ${ }^{67}$ & liver and spleen positive & ND & ND & negative \\
\hline Bone marrow & negative & HS & nsative & HS \\
\hline $\begin{array}{l}\text { Immunohistologic } \\
\text { findings }\end{array}$ & $\begin{array}{l}\text { liver biopsy: } \\
\text { LBCL, cirrhosis }\end{array}$ & $\begin{array}{l}\text { splenectomy and } \\
\text { liver biopsy: LBCL }\end{array}$ & $\begin{array}{l}\text { liver and splenic } \\
\text { biopsy: LBCL }\end{array}$ & splenectomy and \\
\hline Treatment & chemotherapy & chemotherapy & no & cBCL \\
\hline Liver status & fulminant death & alive & cycles & death caused by \\
fulminant hepatitis & alive
\end{tabular}


Fig. 1. Bone marrow aspiration. Macrophage with phagocytosis of erythrocytes and platelets (hemophagocytosis).

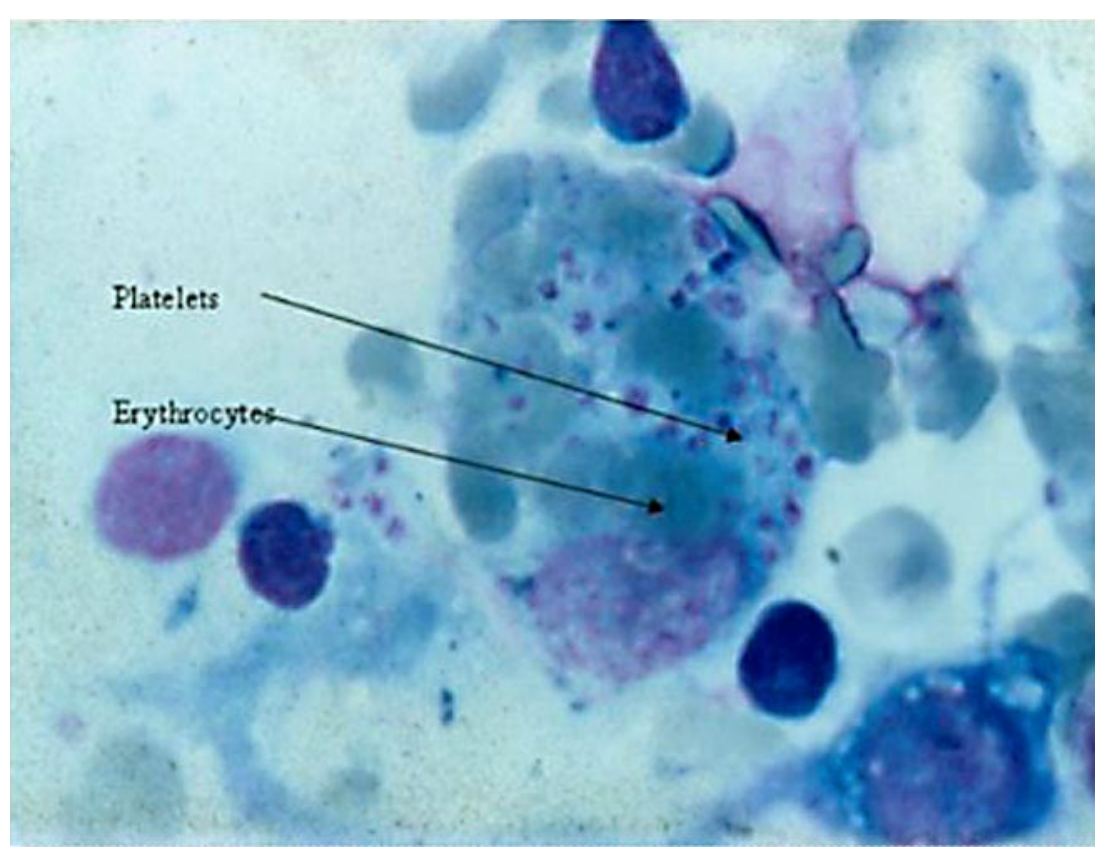




\section{References}

1 Zucca E, Roggero E, Bertoni F, Cavalli F: Primary extranodal non-Hodgkin's lymphomas. Part 1: Gastrointestinal, cutaneous and genitourinary lymphomas. Ann Oncol 1997;8:727-737.

-2 Zucca E, Roggero E, Bertoni F, Cavalli F: Primary extranodal non-Hodgkin's lymphomas. Part 2: Head and neck, central nervous system and other less common sites. Ann Oncol 1999;10:1023-1033.

- 3 Vega F, Medeiros LJ, Gaulard P: Hepatosplenic and other gammadelta T-cell lymphomas. Am J Clin Pathol 2007;127:869-880.

-4 Naschitz JE, Zuckerman E, Elias N, Yeshurun D: Primary hepatosplenic lymphoma of the B-cell variety in a patient with hepatitis $\mathrm{C}$ liver cirrhosis. Am J Gastroenterol 1994;89:1915-1916.

-5 Kwon S, Lee J, Chung I, Kim H, Park M, Kim H, Park C: Hepatosplenic B-cell lymphoma associated with hemophagocytic syndrome: A case report. J Korean Med Sci 1999;14:671-674.

6 Yoshikawa M, Yamane Y, Yoneda S, Iwasawa S, Nishimura K, Kawamoto H, Nakno H, Fukui H, Nakamine H: Acute hepatic failure due to hepatosplenic Bcell non-Hodgkin's lymphoma in a patient infected with hepatitis $\mathrm{C}$ virus. J Gastroenterol 1998;33:880-885.

7 Gil J, Rodríguez C, del Toro J, Montenegro T, Fernández-Cruz E, Menarguez J: Fulminant hepatosplenic B cell lymphoma in a young patient with HCV-chronic hepatitis. Leukemia 1998;12:1005-1006.

8 Grosskreutz C, Troy K, Cuttner J: Primary splenic lymphoma: Report of 10 cases using the REAL classification. Cancer Invest 2002;20:749-753.

-9 Agmon-Levin N, Berger I, Shtalrid M, Schlanger H, Sthoeger ZM: Primary hepatic lymphoma: A case report and review of the literature. Age Ageing 2004;33:637-640.

10 Aung W, Koslosky W, Chin N, Pincus M: Diffuse large cell lymphoma of B-cell type associated with reactive hemophagocytosis. Ann Clin Lab Sci 1996;26:433436.

11 Dommann C, Zimmermann D, Hasam S, Odermatt B, Risti B, Maurer R: T cell rich $B$ cell lymphoma associated with hemophagocytic syndrome. Verh Dtsch Ges Pathol 1992;76:122-125.

12 Simrell CR, Margolic JB, Crabtree GR, Cossman J, Fauci AS, Jaffe ES: Lymphokine-induced phagocytosis in angiocentric immunoproliferative lesions (AIL). Blood 1985;65:1469-1476. 